\section{Success for All? A Call to Re-examine How Student Success Is Defined in Higher Education}

Maryrose Weatherton* and Elisabeth E. Schussler

tDepartment of Ecology and Evolutionary Biology, University of Tennessee, Knoxville, TN 37996

\begin{abstract}
A central focus in science education is to foster the success of students who identify as Black, Indigenous, and people of color (BIPOC). However, representation and achievement gaps relative to the majority still exist for minoritized students at all levels of science education and beyond. We suggest that majority groups defining the definitions and measures of success may exert "soft power" over minoritized student success. Using a hegemonic and critical race theory lens, we examined five years of research articles in CBE-Life SCiences Education to explore how success was defined and measured and what frameworks guided the definitions of student success. The majority of articles did not explicitly define success, inherently suggesting "everyone knows" its definition. The articles that did define success often used quantitative, academic outcomes like grade point average and exam scores, despite commonly cited frameworks with other metrics. When students defined success, they focused on different aspects, such as gaining leadership skills and building career networks, suggesting a need to integrate student voice into current success definitions. Using these results, we provide suggestions for research, policy, and practice regarding student success. We urge self-reflection and institutional change in our definitions of success, via consideration of a diversity of student voices.
\end{abstract}

\section{INTRODUCTION}

Within the United States, there has been a substantial increase in minority populations over the last 10 years, with the United States projected to be "majority minority" by 2045 (Vespa et al., 2018). However, this demographic shift has not been mirrored within the scientific disciplines in higher education; while more than $30 \%$ of the U.S. population identifies as Black, Indigenous, or other person of color (BIPOC), those groups represent only $21 \%$ of science, technology, engineering, and mathematics (STEM) bachelor's recipients. Furthermore, BIPOC only represent 13\% of STEM doctoral recipients, $11 \%$ of the STEM workforce, and 4\% of R1 faculty (National Science Foundation [NSF], 2018). The trend is similar within the domain of biological sciences, where BIPOC students represent $12 \%$ of earned doctorates and $11 \%$ of postdoctoral fellows (Meyers et al., 2018). These differentials in degree acquisition and faculty representation can cascade down to undergraduate and secondary education students. For example, universities lacking diversity in their faculty ranks may see increased stereotype threat to BIPOC students (Nouwen and Clycq, 2018; Park et al., 2020). This can inhibit students' development of a sense of belonging (Good et al., 2012; Hurtado et al., 2015), and negatively affect students' persistence, well-being, and academic achievement.

Differentials in student success have been discussed for at least a quarter century within education research (Panos and Astin, 1968; Boland et al., 1978; Leman, 1999), with countless interventions, theoretical models, and diversity initiatives proposed to increase the success of BIPOC students at all levels STEM education. However, the state of BIPOC representation and persistence would suggest that these initiatives have not succeeded within STEM domains broadly or the field of biological sciences specifically. We argue in this Essay that the assumed definition of "success" and its
Kimberly Tanner, Monitoring Editor Submitted Sep 29, 2020; Revised Dec 17, 2020; Accepted Dec 30, 2020

CBE Life Sci Educ March 1, 2021 20:es3 DOI:10.1187/cbe.20-09-0223

*Address correspondence to: Maryrose Weatherton (mweath13@avols.utk.edu). (C) 2021 M. Weatherton and E. E. Schussler. CBE-Life Sciences Education @) 2021 The American Society for Cell Biology. This article is distributed by The American Society for Cell Biology under license from the author(s). It is available to the public under an Attribution-Noncommercial-Share Alike 3.0 Unported Creative Commons License (http://creativecommons.org/ licenses/by-nc-sa/3.0)

"ASCB®" and "The American Society for Cell Biology $\circledR^{\prime \prime}$ are registered trademarks of The American Society for Cell Biology. 
associated metrics may be one factor hindering the very success of the populations we seek to advance.

\section{What Is Success?}

To study and facilitate student success, we must first understand what we mean when we say "success." As with other broad terms like "interest" (Rowland et al., 2019), the term "success" has a variety of meanings both within and outside the domain of biology education. Student success can be seen in terms of outcomes, like persistence, increase in self-efficacy, and publication rate. However, these concepts can just as easily be seen as components that facilitate success if it is defined as achieving a particular goal. Furthermore, there can be a stark difference in how faculty and students define success (Dean, 1998; Thompson and Jensen-Ryan, 2018), as well as how minoritized students (which we use here to include BIPOC, first-generation, low-socioeconomic status, or other underrepresented groups of students) and their majority counterparts define the term (Tierney, 1992; Goyette and Xie, 1999; Oh and Kim, 2016; O'Shea and Delahunty, 2018). For example, in a study at a public California university, Oh and Kim (2016) found that Korean-American undergraduate students most often defined success as reaching the highest levels of academic achievement, while Mexican-American students most often defined success as going to a 4-year university, surpassing the success of their parents, and helping future students find success (Oh and Kim, 2016). These definitions were further aligned with different support needs and levels of student satisfaction. Thus, the meaning of student success depends on the context as well as who you ask, making a singular, unifying definition largely impossible.

Within biology education, we believe that our current definitions of success may lack the requisite diversity to fully capture the contexts of all students. These definitions inform the metrics used in, and conclusions drawn from, empirical research in the field. These, in turn, inform the policies and practices we advocate for, which ultimately affect student outcomes (Figure 1 ). These definitions are most often created and maintained by those who hold power in the field (e.g., researchers, faculty members, deans, and other university staff), and rarely include meaningful student input, especially from minoritized populations. If these definitions are not created by and for a diverse population, then there will be cascading impacts on outcomes for those left out of the conversation.

We argue that our current limited discourse around the meaning of student success is maintained, in part, by social hierarchies that can be examined through the lens of hegemony and critical race theory, which are described in the next section. These forces unwittingly reinforce and reproduce social hierarchies within our education system that may hinder the success of certain student populations who may not define success in the same way the majority does. Thus, we argue that a critical evaluation of success within higher education is imperative. In this Essay, we hope to start a conversation surrounding what success means, who should define it, and how an expansion of our definitions may help to facilitate the success of all students.

\section{Why Social Hierarchies Are Relevant to the Definition of Success}

The ideas presented in this Essay assume an institutional reproduction of social hierarchies and are framed by cultural hege-

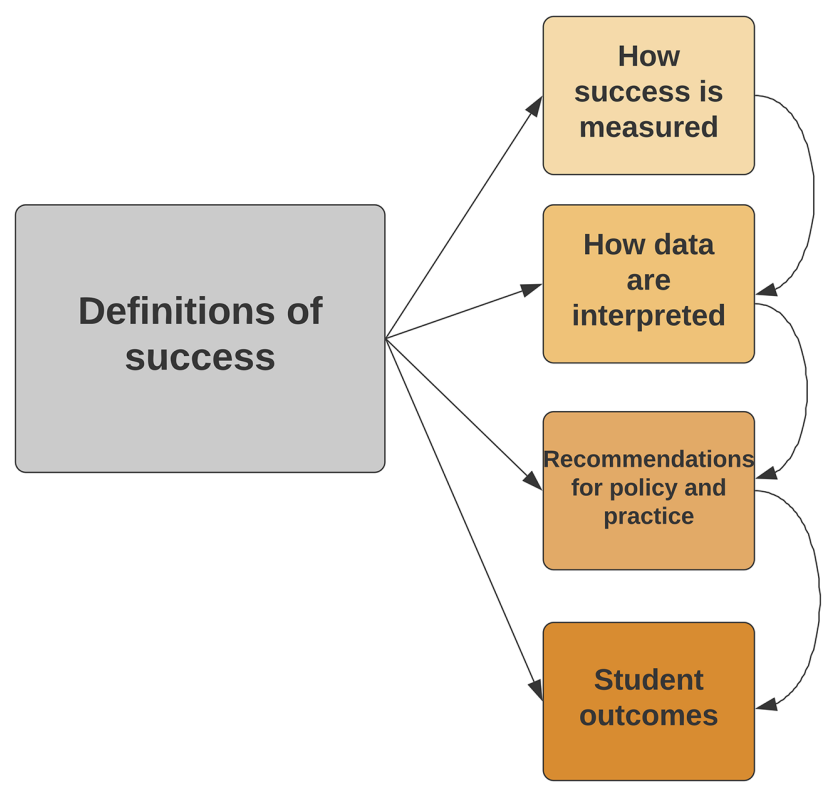

FIGURE 1. How success is defined impacts almost every facet of the research process, as well as policies and practices, and ultimately affects student outcomes. Researchers' definitions of success will impact how they choose to measure the construct, which in turn will impact how data are interpreted and thus what recommendations are proposed. These recommendations often have real-world impacts on student outcomes in higher education in the form of changes in policy or practices such as pedagogies or departmental requirements.

mony and critical race theory. Gramscian hegemony is used to explain the power relations between dominant and minority groups. Specifically, it explains the ways in which dominant groups exert "soft power" over nondominant groups to secure and maintain control within society (Gramsci, 2000; Borg et al., 2002). This is accomplished via manipulation of cultural beliefs, language, values, and norms to establish the dominant group's worldviews as universal, natural, or common sense. These understood rules of society are often invisible, yet powerful. Alternative perspectives, norms, and values are actively discredited by making them seem counterintuitive or unnecessary (Grimm, 2015). However, these counterhegemonic ideas are often the values and perspectives held by nondominant members of society. Hegemony is thus maintained, because one cannot hold dissenting ideologies and also achieve social mobility, reinforcing existing social hierarches and forcing minority groups to conform to these dominant structures (Dawson, 1982; Gramsci, 2000).

We can examine the hegemonic forces underlying student success using ideas from critical race theory (CRT). CRT challenges dominant narratives around race and racism in education and identifies how these narratives are often used to subordinate minoritized groups and maintain white supremacy in the United States (Solorzano 1997; Yosso, 2005; Ladson-Billings and Tate, 2006). Solorzano and Yosso (2001) point out that racial stereotypes form the basis for the dominant "deficit notions" of BIPOC. For example, a common narrative in the United States is the idea of meritocracy, or "pulling yourself up by the bootstraps," whereby minoritized groups can find 
success if they work hard enough (Collins, 2018; McGee, 2020). This narrative shifts blame for unequal outcomes (e.g., wage gaps, lowered academic persistence and achievement) to minoritized groups who "don't work hard enough" or are deficit in some other way, instead of recognizing the structures and institutions that center power with the majority. Within academia, these stereotypes establish a cultural norm that is upheld through differences in expectations, school funding, and punishment between BIPOC and white students (i.e., the school-toprison pipeline; Solorzano, 1997; Barnes and Motz, 2018). While seemingly inert, these dominant frameworks translate into policies and structures that harm minoritized students (Solorzano and Yosso, 2001). For example, school tracking systems (Rosenbaum, 1976; Southworth and Mickelson, 2007), intelligence testing (Rose, 1976; Solorzano and Yosso, 2001), and disparate resource availability (Tate, 2008; Green et al., 2017) have historically been used to maintain social hierarchies by advancing the education of white students while justifying modern-day segregation and deficit notions of BIPOC students (Solorzano and Yosso, 2001; Yosso, 2005; McGee, 2020). Using a CRT lens allows us to explore how our current definitions and metrics of success do not come from neutral, unbiased, or meritocratic ideals, as is often assumed; instead they have been founded on racist principles. We believe that acknowledging this is an important first step to counter these hegemonic forces and begin to redress the harm that they have done to our students.

Linking hegemony and CRT to the concept of student success, we see that majority power can be maintained in higher education by normalizing a restrictive view of student success (e.g., success as having a high grade point average [GPA]). By focusing on outcomes like productivity and employability, these dominant definitions of success ignore large parts of students' well-being (e.g., social, cultural, or personal outcomes). This can be harmful to students who hold "alternative" definitions of success by making them feel as if they do not belong within academia (Hurtado and Carter, 1997; Hurtado et al., 2015; Goyette and Xie, 1999; Tibbetts et al., 2016). For example, in a study of Latinx undergraduates, Hurtado and Carter (1997) found that students' GPAs were not significantly associated with their sense of belonging. For these students, participation in nonacademic activities like membership in religious or community organizations was significantly related to students' sense of belonging (Hurtado and Carter, 1997). This example suggests that a focus on academic metrics versus other measures, such as social participation, may impede the retention of some minoritized students. Many CRT scholars have noted that within the United States education system, BIPOC students are forced to "assimilate" into dominant, Eurocentric paradigms, including those surrounding work ethic, educational values, and definitions of achievement (Carter and Segura, 1979; Solorzano and Yosso, 2001; McGee, 2020). Minoritized students in academia are thus faced with two choices: integrate into an environment that is misaligned with their identities and actively discredits their beliefs or leave the system (McGee, 2020). When they choose to leave, this attrition of minoritized students from academia not only prevents the field of biology from achieving diversity and equity goals, but it also limits minoritized students' social mobility and therefore reinforces existing social hierarchies.
Certainly, we do not think that institutions or educators who promote individual, quantitative definitions of success do so as an active choice to suppress minoritized students. Because hegemonic power flourishes when cultural norms are taken for granted, ideas of what makes a student successful are often built into our academic systems and assumed to be universally true. Even when educators and researchers may wish to reimagine how success is defined and evaluated, institutional structures like yearly evaluations based on pass/fail rates or GPA requirements for degree progression may leave little room for them to introduce "alternative" definitions of success, such as positive mental health, internal development, or community-based outcomes. Education researchers, as intellectual leaders in the field, have an opportunity to examine and resist dominant social hierarchies by refusing to support hegemonic structures while voicing counter-hegemonic structures and narratives. Foucault (1997) suggests that the "reproductive power" of cultural hegemony can be resisted and fought against through critical discourse and inviting new voices into the conversation. It is indisputable that academic definitions of success are both relevant and useful within higher education; however, we argue that alternative views of success must be normalized to advance institutional and societal goals. Thus, by listening to new voices (e.g., amplifying minoritized students' views of success) and considering new definitions of student success, education researchers can take the first step toward changing the system that is preventing students from achieving success equally.

\section{How Biology Education Researchers Define Success}

One window into the discourse around student success can be found in the empirical literature investigating student success in higher education. We believe that current definitions of student success are limited, and that this is true across STEM domains. However, we have chosen to support our argument by sampling the literature within the domain in which the authors have the most knowledge-biology education. To sample how success is discussed and defined in the literature specific to this domain, we explored education research articles that discussed student success in CBE-Life Sciences Education (LSE) over the past 5 years. We examined 1) whether and how success was explicitly defined within research articles and 2) how success was measured. We also noted what theoretical frameworks seemed to be shaping research on student success. This literature examination was restricted to biology education and not intended to be comprehensive. Instead, this examination is used as an example of how probing the term "success" can reveal a need for researchers to re-examine their assumptions as well as consider how different metrics and a diversity of student voices may lead to a more complete definition of what it means for students to be successful.

We used a standard literature review methodology to collect these data (Creswell and Creswell, 2017). We searched the online database of LSE on June 14, 2020, using the term "success," and limited our search to articles published within the last 5 years (2015-2020). This primary search returned 311 articles, which we further narrowed by selecting only research articles (i.e., not reviews, meeting reports, or editorials). After applying this filter, we were left with 248 results.

As we were specifically interested in how success was defined in higher education, we excluded articles that examined student 
success in K-12 educational settings. Furthermore, we excluded articles that evaluated the success of specific curricular programs (e.g., research examining the success of an intervention aimed at reducing gender bias) as opposed to research on student success, as well as research papers about instructors and faculty, as they did not explicitly study student success. We did not have any exclusion criteria related to subject domain (e.g., math success, physics success, etc.) though most articles published in LSE are related to life sciences education. We also did not exclude any articles on the basis of study time frame or analysis approaches. This left 52 articles related specifically to research on student success in higher education over the last 5 years (see the Supplemental Material for the list of these articles).

\section{The Majority of Articles Discussing Student Success Did Not Explicitly Define the Term}

Of the 52 articles, 21 (40\%) gave explicit definitions of student success. The other 31 defined student success implicitly through the variables they measured, often equating student success with quantitative student outcomes, such as exam scores and GPA. Of the papers that explicitly defined success, there were four broad categories for how the concept was defined: academic, persistence, career, and social (see definitions in Table 1). Academic definitions (e.g., grades, GPA) were the most prevalent in the literature (80\%), followed by persistence (e.g., remaining in major) definitions (47\%). Career definitions included obtaining a job in STEM (15\%). The least common category was social definitions (4\%), with only one paper explicitly defining success as it was related to students becoming leaders in their communities. Each article with an explicit definition could be placed in one or more of these four categories.

\section{There Were Many Different Ways to Measure Success, and Most Were Quantitative}

Overall, there were 30 distinct measurements of student success in the articles, 13 of which were mentioned more than once. The majority of papers ( $88 \%$ ) measured at least one quantitative outcome related to student success; only six papers captured solely qualitative metrics. Of the papers that measured quantitative outcomes, the most common measure of student success was a suite of persistence measurements, followed by exam scores and course grades (Table 2).

Persistence as a measure of student success came up often and in many different variations in the articles. In total, 20 articles (38\%) measured student success as some aspect of persistence, attrition, or retention (Table 2). We separated these into five subcategories based on the authors' description of the outcome variable. Articles that reported "retention" and "persistence" generally were sorted into the first subcategory: "persistence/retention general." Most often, papers in this subcategory measured persistence or retention in a degree program. Further, "persistence/retention in major" and "persistence/ retention in a STEM field" were two different subcategories, with the former being explicitly about changes in students' declared major, while the latter included postgraduation outcomes, like attaining a career in a STEM field or continuation to a STEM graduate degree. The outcome "intention to persist/ remain" was based on student expectations versus actual retention or persistence from a major or course. Finally, there was only one article within the subcategory of "attrition" (Wilson et al., 2018); this article measured the percent of graduate students that left their programs without an MS or $\mathrm{PhD}$ degree over a period of 8 years.

\section{Theories of Student Success Have Changed over Time}

As part of the framing for their student success studies, many of the articles cited one or more theories or theoretical frameworks that guided their work. Across the articles we examined, 23 theories were cited, and five were mentioned within multiple papers: self-efficacy, identity, sense of belonging, social cognitive career theory, and social interdependence theory. Theoretical frameworks can influence almost every aspect of a study, from how the research questions are framed, to how concepts are understood and defined, what data are collected, and how the results are interpreted and situated within the broader field (Anfara and Metz, 2014; Creswell and Creswell, 2017; Rowland et al., 2019). In studies of student success, the theoretical frameworks that researchers chose likely influenced how they defined success or the success outcomes they hoped to measure. These theoretical frameworks, then, can be vehicles of

TABLE 1. Categories of explicit definitions of student success represented in the literature sample $(N=\mathbf{2 1}$ articles that defined success explicitly out of 52 total articles)

\begin{tabular}{|c|c|c|c|}
\hline Category & Definition & $\begin{array}{c}\text { No. of } \\
\text { papers using }\end{array}$ & Representative quote \\
\hline Academic & $\begin{array}{l}\text { Describe success as obtaining positive } \\
\text { academic outcomes, like grades, } \\
\text { GPAs, or exam scores. }\end{array}$ & 17 & $\begin{array}{l}\text { "Because we did not have an a priori prediction of whether delayed } \\
\text { re-quizzing would help students with differing incoming biology } \\
\text { knowledge (pretest score) or differing success in previous STEM } \\
\text { course work (chemistry final exam score), we added both interac- } \\
\text { tion terms into our model in step 3." (Walck-Shannon et al., 2019) }\end{array}$ \\
\hline Persistence & $\begin{array}{l}\text { Describe success as students remaining } \\
\text { in a major, program, or within STEM } \\
\text { broadly. }\end{array}$ & 10 & $\begin{array}{l}\text { "Success was defined as a student remaining in a course between } \\
\text { registration and the end of the course and receiving a grade of "C" } \\
\text { or better." (Gregg-Jolly et al., 2016) }\end{array}$ \\
\hline Career & $\begin{array}{l}\text { Describe success as some factor related } \\
\text { to career outcomes, like obtaining a } \\
\text { career in STEM or intention to } \\
\text { pursue a STEM career. }\end{array}$ & 8 & $\begin{array}{l}\text { "Given that they [participants] had positions in research careers, all } \\
\text { respondents were presumed to be successful." (Martinez et al., } \\
\text { 2018) }\end{array}$ \\
\hline Social & $\begin{array}{l}\text { Describe success as some factor related } \\
\text { to interpersonal relationships, like } \\
\text { facilitating community leadership }\end{array}$ & 1 & $\begin{array}{l}\text { "Collective success underpinned the Āwhina kaupapa (goal) of } \\
\text { producing STEM professionals who would become leaders in Māori, } \\
\text { Pacific, and other minority communities." (Richardson et al., 2018) }\end{array}$ \\
\hline
\end{tabular}


TABLE 2. Measurements of student success (outcome variables) represented more than once in the literature sample $(N=52)$

\begin{tabular}{lc}
\hline Outcome variable & $\begin{array}{c}\text { No. of papers using } \\
\text { this measure }\end{array}$ \\
\hline Persistence/retention/attrition & 20 \\
Persistence/retention general & 9 \\
Persistence in STEM field & 5 \\
Intention to remain in STEM field & 4 \\
Persistence in major & 1 \\
Attrition & 1 \\
Exam scores & 16 \\
Course grades & 10 \\
GPA & 9 \\
Student attitudes & 8 \\
Graduation/degree attainment & 7 \\
Number of publications & 4 \\
Self-efficacy & 3 \\
Identity formation & 3 \\
Sense of belonging & 3 \\
Time to completion & 2 \\
\hline
\end{tabular}

hegemonic influence that set the standard for how student success is measured and discussed and are thus integral to consider. We will discuss the evolution of the discourse around student success in order to add context to these frameworks and inform our discussion about how to expand our definitions of success.

Although the term "student success" has been discussed in the education literature for more than a century (Carmichael, 1913; Alexander and Woodruff, 1940; Brogden and Taylor, 1950), most of the theories or frameworks mentioned in the articles we examined were more recent in origin. The five most commonly cited theories in the articles originated within the biology education literature over the past 30 years. However, this empirical research was built on work done in the past, meaning that even these newer conceptions can have old ideas embedded in them that perpetuate racist stereotypes and ideals.

Popularized in the 1950s and 1960s, universal quantitative measures (e.g., ACT, Scholastic Aptitude Test, Graduate Record Examination scores) were some of the first measures of student success (Capps and Decosta, 1957; Kunhart and Olsen, 1959). Early theories of student success proposed success as an outcome based on inherent qualities, like personality (Robertson and Hall, 1964). In the 1970s and 1980s, work on student socialization and integration popularized one of the most commonly used metrics of success, persistence (Table 2). Theories during this time built upon previous work by examining how students' personal characteristics impacted their interactions with their environments, like Tinto's (1975) theory of student attrition. As the "positive psychology" movement gained traction in the 1990s and 2000s, more modern theories layered "internal development" factors, like motivation and self-regulation, on top of the interactions among personal characteristics and proximal environmental influences to explain student success. For example, social cognitive career theory claims that increasing students' feelings of self-efficacy and providing them with relevant learning experiences can mediate background and proximal environmental influences on their career decisions and goal attainment (Lent et al., 2002). This layering introduces new ideas but retains core older ideas about student success.

While new ideas of success push the field forward, much of the discussion is still framed by antiquated, racist notions that undermine these theories' ability to reflect the experiences of BIPOC students. For example, Binet's IQ test has been used to justify "genetic determinism" models of minority education equality (Rose, 1976; Solorzano and Yosso, 2001). And although the field's most influential theories are assumed to be broadly applicable, many of them were developed solely on the basis of majority students. For example, Tinto's influential institutional departure model (1975) has been critiqued for its exclusive study of "traditional" students (i.e., white, upper-class students) at "traditional" universities (i.e., primarily white, residential, 4-year institutions; Astin, 1985; Attinasi, 1989; Tierney, 1992; Tinto, 1993). These limited populations bounded the results drawn from the theory. This has led, for example, to the problematic conclusion that students must detach from their previous communities in order to find success in higher education. Indeed, the opposite has been found for minority and first-generation students, many of whom draw strengths from their connection to their home communities and cultures (Muñoz and Maldonado, 2012; Yao, 2015; Burt et al., 2019).

The use of majority students as the foundation for the theories central to the ideas underlying student success is not only problematic, but harmful to minoritized students. When historically underrepresented students do not meet the standards of success established by the theories (e.g., higher attrition rates, lower course grades, etc.) it is assumed that the deficiencies are on the part of the students, and not the theory. As previously mentioned, this "deficit notion" of BIPOC students prevents equitable outcomes between BIPOC and white students. It also forces minoritized students to choose whether to conform to the majority standards of success or live within a system that does not value what they consider to be successful.

Despite the expansion of our theoretical understanding of student success over the past century, many of our definitions and metrics of success have been stubbornly unchanging. We acknowledge that the practicality and ease of quantitative metrics may be one reason why they are so prominent when measuring student success. It takes much less time to gather the course grades of each student in an introductory biology class than it does to collect interview data about their perspectives on success in the course, for example. Furthermore, latent constructs like student well-being or identity are more difficult to measure compared with academic metrics like GPA, as the former are made up of multiple, diverging indicators, and alternative ways to measure these constructs may not yet have been developed and validated for wider usage. Of course, quantitative metrics can have predictive value and can be excellent tools to answer many research questions. However, we argue that measuring quantitative outcomes is not a panacea for understanding how students achieve success in academia. Thus, we argue that, without addressing the ideas that underlie our notions of success, the field will continue to struggle to address the needs and facilitate the success of all of our students.

\section{Who Gets to Define Student Success?}

Of the 52 articles in LSE that discussed student success over the past five years, only one article captured students' own 
definitions of success, suggesting a paucity of research in this area. This presents an issue if students have different definitions of success than those who determine the field's definitions, like researchers and institutional decision makers. Indeed, Thompson and Jensen-Ryan (2018) found that undergraduate students expressed definitions of success that included academic outcomes like graduation as well as emotional outcomes, such as not getting discouraged and increasing their self-efficacy and self-confidence. Many students from historically underrepresented backgrounds (e.g., BIPOC, low-socioeconomic status, first-generation students) reject traditional definitions of success. For example, O'Shea and Delahunty (2018) found three themes of success that emerged from interviews with first-generation undergraduates: success as a form of validation, success as defying the odds, and success as positive feelings about one's trajectory. Interestingly, many of the students interviewed had very clear ideas of what success was not, including obtaining high grades or passing exams (O'Shea and Delahunty, 2018).

Considering these examples of how students' and researchers' perspectives on success can differ, we ask why student voices are so rare in the literature on student success. One explanation goes back to the idea of hegemonic power, wherein members of the majority impose their worldview as cultural "common sense" (Boggs, 1976, p. 39). Within academia, hegemonically imposed worldviews can present themselves via the belief that definitions of certain terms are homogeneous and that explicitly defining terms like "success," "persistence," and "interest" is not necessary. Indeed, our examination of the literature on student success found that success was only explicitly defined in $40 \%$ of the articles we examined. Even when success is defined, researchers and other institutional stakeholders may experience difficulty thinking beyond traditional definitions, as they often realized their positions via traditional success measures (e.g., academic success). Thus, the problem becomes apparent-if most researchers define success in similar ways, and these definitions are validated by achieving intended career outcomes, then these definitions are taken for granted and seen as common sense. Therefore, researchers may not see the need to gather student perceptions of any concept whose definition seem so inherent.

In this way, hegemonic influence is hidden within everyday facets of academia, like the language we use to describe and define concepts. However, a critical examination of the discourse surrounding these concepts can reveal a startling lack of ideological diversity. We argue that the hegemonic framing of embedded discourse prevents the field from moving forward toward more inclusive definitions and metrics. To resist this framing, we must collectively examine and make concrete changes to many of the aspects we have discussed here: how success is defined and measured and whose success we are concerned with. As a community of researchers, we have the collective power to expand our own and our institutions' discourse in order to validate and facilitate all students' definitions of success. To that end, we present recommendations in the realms of research, policy, and practice that aim to amplify minoritized student voices, encourage deep self-reflection, and bring about equitable institutional change.

\section{RECOMMENDATIONS}

The purpose of this Essay was to examine success through a hegemonic and CRT lens to inform a collective discussion about how our current perspectives on student success may be contributing to unequal attainment of success. Despite a concentrated effort over the past 25 years to increase BIPOC "success" in STEM domains, gaps between BIPOC students and their majority counterparts still exist at all levels of STEM education and beyond (NSF, 2018; Meyers et al., 2018). Although the field's ideas and theories of student success have evolved and gained more nuance over the past 70 years, our definitions and measures still fall short of being fully inclusive. Our limited examination suggests that current definitions and metrics of student success are mostly academic and quantitative and are most often defined by institutional-level stakeholders, such as researchers. Although these theories were developed via research directed at students, there is a paucity of literature that directly asks students their views on success in higher education. Here, we propose recommendations for individual researchers to more explicitly consider success and center student voice in their empirical work. We then provide recommendations for the community as a whole within the areas of research, policy, and practice.

\section{Recommendations for Individual Researchers}

To encourage researchers to more critically examine their potential role in the reproduction of social hierarchies in academia, we recommend that they consider their own definitions of student success and how these definitions influence their empirical work. Furthermore, we encourage researchers to consider what definitions of success are highlighted within their research and how they can amplify diverse perspectives and voices within that research. Explicitly considering what perspectives of success they intend to use before beginning their projects will allow researchers to clearly ground their work and accurately describe what they intend to study, which in turn will lead to clarity in definitions, proposed metrics, and interpretation of results.

To foster these reflections, we model from Rowland et al. (2019) the presentation of guidelines and associated guiding questions for researchers to use as they begin projects investigating student success in higher education:

1. Before beginning their research, researchers must self-reflect on the biases, hegemonic frames, and societal norms that they have internalized simply as members of society. Much like the qualitative practice of bracketing, this process will not rid researchers of any biases, but makes them visible, so researchers can reflect on how these biases may shape their interpretations (Creswell and Miller, 2000). For resources to guide self-reflection and examination of internal biases, see Gullo et al. (2018), Killpack and Melón (2016), Project Implicit (2011), and Racial Equity Tools (2020).

2. Researchers should discuss and agree upon their definition(s) of student success before beginning their research. This decision may be guided by funding sources, participant populations, research questions, and/or guiding theoretical frameworks. Questions:

i. Does my funding source require institutionally relevant data, like student retention or GPA? If so, does my definition align with these metrics? Do I need to add a second definition if I am collecting other metrics? 
ii. How diverse is my intended study population? Are there definitions of success that may more closely align with the views of my intended population?*

iii. How might my study accurately capture the perspectives of minoritized students, as opposed to invoking "safe multiculturalism" (i.e., an unchallenging, stereotypical, or tokenized view of a culture)? For more information on safe multiculturalism, see May and Sleeter (2010) and Yancy (2016).

iv. Do my intended research questions and theoretical frameworks align with the definition(s) of student success I am considering?

3. Researchers should confirm that the intended metric(s) of success align with the chosen definition(s) within their project. Questions:

i. Based on my definition, how many measures of success do I need to use?

ii. Should the definition of success be captured using quantitative or qualitative metrics? If I can use both, is one more appropriate given my intended population,* study context, and time constraints?

iii. Am I sure that students define success in the way I am intending to measure it? *

4. Researchers should justify the reason for using their chosen definition(s) of success over others and acknowledge the limitations that their chosen definition(s) might present. Questions:

i. Have I chosen this definition of success over others simply because its associated metrics are easy to measure?

ii. Have I explicitly defined success in any communications about my project?

iii. Have I sufficiently articulated a rationale for my definition and measures?

iv. How might the definition of success used in my project be a potential limitation of the study? Have I acknowledged that as part of the study?

*If the answers to some of these questions are unknown, researchers may want to consider a pilot study or a qualitative inquiry into these students' definitions of success.

We hope the use of these guidelines and associated questions will help researchers appropriately conceptualize success in each study they undertake and encourage researchers to consider how to capture diverse voices and perspectives within their research.

\section{Recommendations for Research, Policy, and Practice}

The following section focuses on actions the community can take to disrupt the current thinking about student success in order to reframe it for all students. To reflect the full diversity within STEM, and in consideration of the lack of student voice in the current literature, we suggest a need to truly listen to student perspectives on success at all levels. Lack of student voice is widespread across many domains; indeed, this issue has garnered the attention of the United Nations, which in 2009 proposed "General Comment No. 12-The Right of the Child to be Heard" (UN, 2009). In 2002, the UN Committee on the
Rights of the Child (UNCRC) documented its concern that "in education, schoolchildren are not systematically consulted in matters that affect them" (UN, 2002). We suggest that similar issues are present in higher education, even though the majority of our students are considered adults.

In 2007, Lundy proposed a model to conceptualize article 12 of the UNCRC, and we are adapting it here to guide discussions about how to highlight student voice in research on student success and bring meaningful change within the realms of policy and practice (Figure 2). Article 12 delineates two key rights: 1 ) the right to be heard and 2) the right to have one's views given due weight (Lundy, 2007). To successfully implement article 12, Lundy proposed that four elements must be considered: space, voice, audience, and influence. The first two elements, space and voice, relate to students' rights to be heard. The next two elements, audience and influence, relate to students' rights to have their views given due weight. We propose that the first two elements of Lundy's model can be used to inform recommendations for research, and the latter two elements can be used to inform recommendations for research, policy, and practice.

Students' Rights to Be Heard-Recommendations for Research. A prerequisite for meaningful engagement with students requires the recognition that their opinions are necessary and valid. In regard to discussions of student success, this means we must create space in our discourse where alternative definitions of success are not only allowed but are honored as equally valuable. We believe that the process of making this space can start with this Essay and subsequent conversations. This space will allow the field to begin the process of examining the current hegemonic structures that dominate academia and work to dismantle them.

Student voice is critical to this process. This can be accomplished either informally, through conversations between students and mentors; or formally, through qualitative research regarding how students define success. Involving students in the research process is an empowering way to amplify student voice in our discussion of student success. When applicable, we suggest that researchers employ a community-based participatory research approach, a research strategy that equitably involves community members and researchers in a way that seeks to validate community members' expertise and empowers non-researchers by sharing the decision-making process (see Minkler and Wallerstein, 2011). We also point out that the need to listen to students includes both undergraduate and graduate students. Research on graduate student success is even more limited than for undergraduates, and given the high attrition of graduate students from STEM degree programs (Chen, 2013; Sowell et al., 2015), it is important to also capture their unique perspectives. These conversations can add critical, new perspectives needed by researchers and institutional stakeholders to steer the field in a new direction.

Students' Rights to Have Their Views Given Due WeightRecommendations for Research and Policy. Lundy (2007) recognized that making space and gathering student voice do not necessarily mean that student perspectives will be appropriately heard or acted upon. Indeed, ensuring students maintain their rights is often difficult, especially when their views 


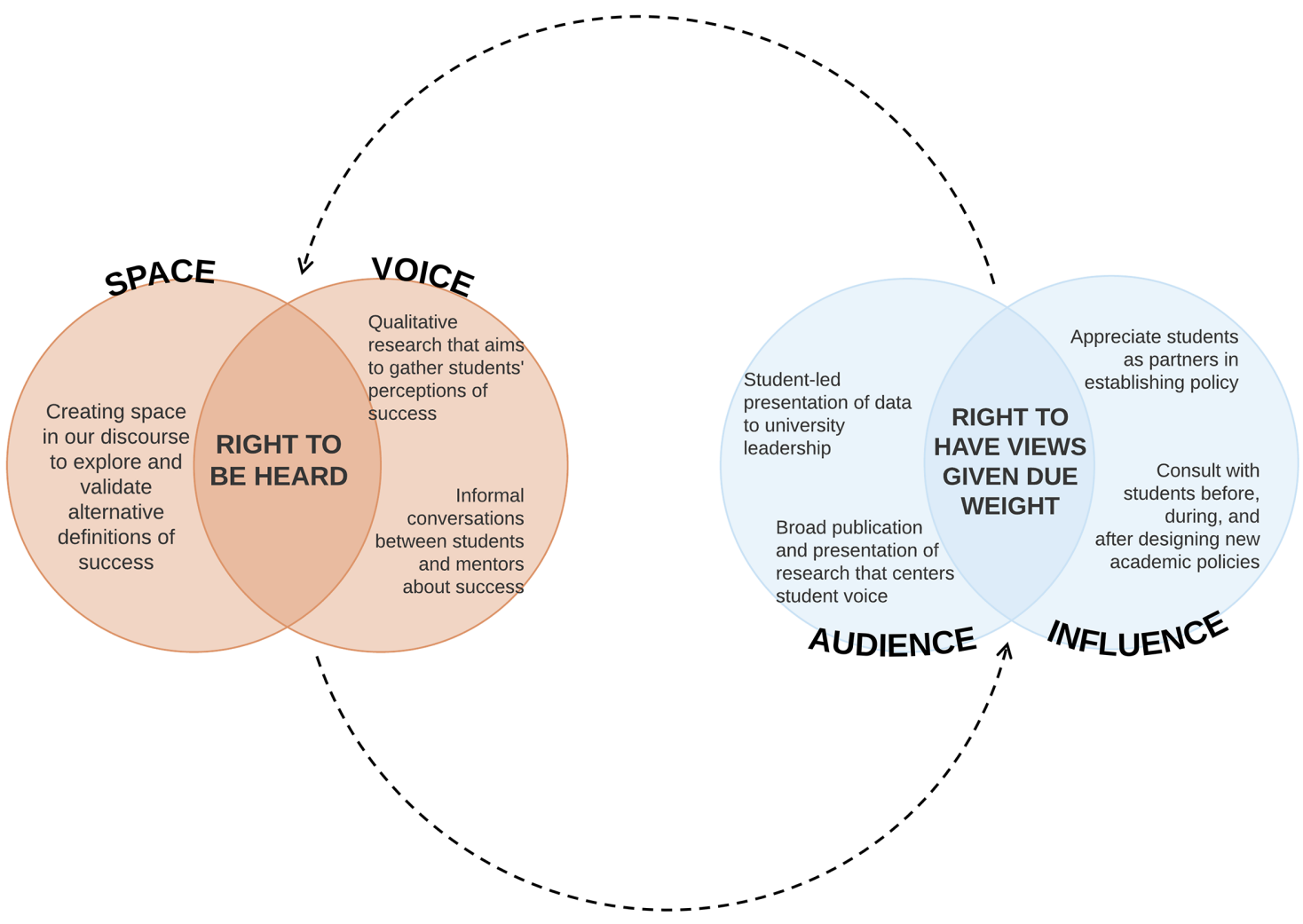

FIGURE 2. This figure highlights four key elements from Lundy's model, two relating to one's right to express a view-space and voiceand two relating to one's right to have their views given due weight-audience and influence. These rights are highly interrelated, and when examined in an academic context, lead to an iterative process for working with students to bring equity to the domains of policy, practice, and research.

challenge the dominant thinking, are expensive to enact, or cause controversy (Lundy, 2007). It is important that we are attentive to the latter two elements in Lundy's model-audience and influence-as merely gathering student perspectives without enacting change (i.e., tokenizing student voice) will not combat systemic issues and may, in fact, be counterproductive (Alderson, 2000).

Students' perspectives must be presented to the appropriate audiences in order for them to have any influence over research, policy, or practice. Thus, stakeholders at all levels of academic institutions must be exposed to these voices. This can be accomplished broadly through publication and presentation of work that foregrounds student voice and locally through initiatives that present students' opinions to provosts, deans, department heads, faculty, and other university leadership staff to inform new policies. The UNCRC has warned that "appearing to 'listen' to children is relatively unchallenging; giving due weight to their views requires real change" (UN, 2003, para. 12).

Individuals (e.g., researchers, students, and staff members) must be engaged in the process of amplifying student voices and expanding our understanding of student success. However, for these recommendations to have lasting effects, the need to expand how success is defined and measured must be understood and enacted by academic institutions and organizations in the field (e.g., NSF, Association of American Universities, American Academy for the Advancement of Science [AAAS]). We discuss this more in the following section. Fur- ther, while we present two broad policy suggestions, we urge policymakers to see students not just as respondents or data points, but as partners and cocreators in establishing appropriate policy that serves their unique student populations. For a more in-depth guide to including students in this process, see Lygo-Baker et al. (2019).

First, we suggest that universities have a policy to incorporate nonacademic measures of success into components of course work or within graduate student evaluations. Many studies have revealed that student mental health and persistence, among other outcomes, are highly impacted by nonacademic factors (i.e., not related to course or grade outcomes) such as creation of a professional network (Sweitzer, 2009), development of metacognitive regulatory strategies (Green and Macauley, 2007; Efklides et al., 2018; O'Shea and Delahunty, 2018), and establishment of students' academic identities (McAlpine and Amundsen, 2009; Oh and Kim, 2016; Schnoes et al., 2018). Depending on students' definitions of success, these factors may be as important, if not more important, than traditionally evaluated outcomes, like GPA, exam scores, or time to degree. This policy would work to honor alternative definitions of success and thus increase sense of belonging for all students in academia. Moreover, incorporating a larger diversity of success metrics will grant advisors, departments, and institutions a more holistic picture of student development and progress.

Second, we suggest that universities add or amplify nonacademic support for students that honors alternative definitions 
of success. The current hegemonic framing of student success encourages a large amount of institutional support to go toward facilitating academic definitions of success (e.g., tutoring centers, peer coaches, academic advising). While these supports are useful and integral to many students, support structures for nonacademic definitions of success can be equally important to students. Thus, we suggest directing more funding to services such as career centers, which support career-based definitions of success (Gallup, 2016); multicultural student centers and groups, which support community-based definitions of success (Bell, 2016; Tachine et al., 2017); and mental health support, which can work to support definitions of success that include personal growth and development (Biasi et al., 2017; Vescovelli et al., 2017). By truly listening to, and acting on, the unique voices of students, university leaders can enact changes in institutional policy and structure that may be more likely than current initiatives to facilitate success for all students.

\section{Rethink, Reframe, Start a Conversation- Recommendations for Practice}

Our goals to increase representation of minoritized students in STEM, to improve student well-being, and to facilitate student success will only be met once all definitions of success are represented and supported in higher education. However, faculty play a role in everyday interactions with students that can be powerful influencers of success as well. Our perspectives, our biases, our words matter, and we need to carefully reflect on our individual influence. Do we think that graduate students are more successful if they become R1 faculty after graduation than if they become science journalists? Do we have a problem if undergraduates entering our classrooms see success as a "C" as opposed to an "A"? These biases, which come from our own backgrounds as students and researchers, are seemingly innocuous; however, they impact how we interact with students in one-on-one meetings, during office hours, and in the classroom, and therefore impact how supported students feel. Noncontent talk, or the things instructors say that are unrelated to the course material (Seidel et al., 2015), could be an important way to expose students to multiple, diverse definitions of success or it may reinforce a hegemonic view of student success in university settings. Attention to our own thinking and words and how they impact our discussions with students may be key to breaking down the cycle of hegemonic reproduction in academia. Finally, it is important to acknowledge the difficult work involved in beginning to unpack and examine the facets of internalized racism that underlie the "simple" idea of student success. This work is necessary to move the field forward and build a more equitable environment with diverse conceptions of success.

\section{ENACTING CHANGE}

We recognize that raising awareness, encouraging self-reflection, and including student voice may not in and of itself change how success is framed. These steps may be critical to changing the perspectives of individual researchers and adding new definitions and metrics of success but may not be enough to change institutional structures that are deeply embedded in racist social hierarchies. Indeed, a central component of our critical race framework is the notion that racism is not an individual issue, but a deeply ingrained systemic condition (Ladson-Billings and Tate, 2006; Solorzano and Yosso, 2001; Vaught, 2011). Thus, in the following section, we highlight some ideas for institutions and organizations to enact lasting structural change as it relates to student success.

First, to properly enact change, we must acknowledge the concept of "empathetic fallacy," or the incorrect idea that changes will be instituted simply because they are the right thing to do (Delgado and Stefancic, 2000). While making the field's definitions and metrics of success more diverse and equitable is the right thing to do, this fact is not enough to shift hegemonic structures. Instead, we have provided a table of the benefits of and risks for not expanding our definitions and metrics of success, which we encourage the community to build on (Table 3). These benefits range from positive impacts on student well-being and retention, to more equitable institutional policies and practices and scientific problem solving. Indeed, Freeman and Huang (2015) found that greater author homophily was associated with publication in lower-impact journals and fewer citations, while the opposite was true with

TABLE 3. Illustrative examples of the benefits of applying recommendations and the risks of not applying recommendations related to broadening the field's metrics and definitions of student success

Overall BENEFITS of applying recommendations

Broader conceptions of success lead to a more diverse, and thus innovative, STEM field.

Student-level: Centering diverse student values and including students in the processes of research and policy development leads to an increased sense of belonging in science.

Student-level: Student-led policy initiatives lead to more apt educational policy, thus increasing student well-being and attainment of science degrees.

Researcher-level: More nuanced metrics of student success lead to a better ability to predict student attrition, achievement, and other outcome variables.

Institutional-level: Broader awareness and critical examination of social hierarchies lays the groundwork for more equitable policies and practices across the institution.

Society-level: Increased diversity of perspectives in science disciplines allows the field to more readily solve complex problems.
Overall RISKS of NOT applying recommendations

Maintenance of harmful hegemonic framing suppresses diversity and actively harms students and science productivity.

Student-level: Mismatches in metrics and definitions of success lead to increased sense of isolation from science for some students.

Student-level: Ill-fitting educational policy leads to student struggles with mental health (e.g., anxiety and depression) and attrition from science fields.

Researcher-level: Current metrics lead to an incomplete ability to make adequate predictions to support students (e.g., how to meet diversity and equity goals, how to foster a competitive workforce).

Institutional-level: Unchecked departmental and institutional biases lead to difficulties attracting and retaining diverse students, staff, and faculty.

Society-level: Continuation of majority approach to science limits new ideas and perspectives. 
more ethnically diverse groups of authors. More diverse teams and institutions solve problems faster (Reynolds and Lewis, 2017), generate more creative solutions (Dezsö and Ross, 2012), and are more resilient in the face of change (Duchek et al., 2020). Beyond the moral imperative for our field to become more equitable, we argue that combating the current hegemonic structures is essential for future innovation, advancement, and evolution of STEM fields. The risks of not applying these recommendations mirror the current issues with the field that we have discussed previously, including maintenance of social hierarchies, poor student mental health, and continued difficulties meeting diversity and equity goals at academic institutions and within society broadly (Table 3 ). However, we also must acknowledge that there are costs to these recommendations that also must be taken into account: institutions and individuals must invest time, resources, and emotional energy into enacting these changes.

Changing definitions of success will also require transformative change at the institutional level and beyond. This type of "deep change" or "second-order change" employs multiple change approaches to impact the attitudes, culture, and structure of organizations (Kezar, 2018) and dislodge the current hegemonic cultures, values, and beliefs that currently exist. Although individuals must change as part of this process (first-order change), second-order change involves explicit questioning of the operational frameworks and assumptions under which an organization functions, thus changing not just practices, but ideologies within an institution (Argyris and Schön, 1997; Kezar, 2018).

In the field of STEM education, the efforts to replace lecturing with active learning is one example of second-order change. The benefits of active learning have been known for many years. Early efforts centered on getting individual faculty to change their practices, assuming that diffusion of these innovations would spread active-learning approaches, which is not what happened (Miller et al., 2000; Bennett and Bennett, 2003; Brownell and Tanner, 2012). To foster broader change, the Vision and Change initiative was started by individuals who realized that the influence of national organizations such the NSF, AAAS, and disciplinary societies could be used to amplify change (AAAS, 2011). A series of forums and conversations with colleges and universities were organized, exemplifying the second-order change principle of providing opportunities for ongoing collaborative reflection within an institution. National conferences brought together leaders in the field and produced two influential conference reports with data, ideas, and exemplars that individuals and organizations used as levers for change. This highlights another principle of second-order change, using data to illustrate the need for change. NSF actively encouraged research on Vision and Change principles, incentivizing individuals and institutions to prioritize these ideas. While efforts related to Vision and Change have not employed all of the recommendations we suggest in this paper (e.g., including student voice in reforms), we believe it is an illustrative example of institutional change that has made great strides in normalizing active learning as beneficial and lecturing as a potentially harmful to students (Freeman et al., 2014, but see England et al., 2019).

Within our discussion of changing definitions and metrics of success, we believe that similar expansive, enduring initiatives are needed. As seen in the case of Vision and Change, institutional efforts can be amplified by disciplinary societies, foundations, and government agencies. These external influencers can also provide broad policy suggestions and funding initiatives to support systemic change. These efforts are time-consuming, but they represent some of the approaches that would be necessary to change the values, beliefs, and institutional culture surrounding the concept of success.

\section{CONCLUSION}

Student success is a central focus of education, particularly uncovering ways in which minoritized students can achieve representation in STEM at levels equivalent to their representation in U.S. populations. We posit that the lack of diversity in definitions and measures of success is an example of hegemonic influence within academia. Hegemonic power may be unknowingly upheld by researchers, faculty, and other institutional-level stakeholders who consider these dominant ideas of success to be "common sense" or standard. These dominant ideas of success, often stemming from racist structures and theories, reinforce social hierarchies within academia, making it more difficult for minoritized students to achieve social mobility (Giroux, 1984). Movements of counter-hegemony are the only way to subsume dominant cultural norms (Pratt, 2004). Thus, we call on researchers to carefully consider their definitions of success and associated metrics, to fully acknowledge how their conceptualization of success impacts their research, and to make space for and solicit student voice in discussions of student success. We further call on institutions and faculty to consider a more holistic view of student success, and when presented with student voice, to not merely listen, but to give their perspectives "due weight." And we call on disciplinary societies, government agencies, and other organizations in positions of power and influence to consider how they may play a role in fostering new definitions of success. Finally, we hope that this Essay sparks collective reflection that leads each of us to consider how we participate in hegemonic reproduction, what biases we operate under, and how we can work in our classrooms, with our advisees, and as advocates, to facilitate student success that is as inclusive as we strive to be.

\section{ACKNOWLEDGMENTS}

We are grateful for the feedback on this article by Miranda Chen Musgrove, Elizabeth Derryberry, Courtney Faber, Nina Fefferman, Joshua Rosenberg, Caroline Wienhold, and Hope Ferguson. We thank the reviewers and editor for their incredibly thoughtful and useful comments on an earlier version of this Essay.

\footnotetext{
REFERENCES

AAAS. (2011). Vision and Change: A Call to Action. Washington, DC: AAAS. Retrieved October 25, 2020, from https://visionandchange.org/about -vc-a-call-to-action-2011/

Alderson, P. (2000). School students' views on school councils and daily life at school. Children and Society, 14, 121-134. https://doi.org/10.1002/ (SICI)1099-0860(200004)14:2<121::AID-CHI588>3.3.CO;2-4

Alexander, N., \& Woodruff, R. J. (1940). Determinants of college success. Journal of Higher Education, 11(9), 479-485. https://doi org/10.2307/1974924

Anfara, V. A. Jr., \& Mertz, N. T. (Eds.). (2014). Theoretical frameworks in qualitative research. Sage.
} 
Argyris, C., \& Schön, D. A. (1997). Organizational learning: A theory of action perspective. (pp. 345-348), Boston, MA: Addison-Wesley.

Astin, A. W. (1985). Involvement: The cornerstone of excellence. Change, 17(4), 35-39. http://dx.doi.org/10.1080/00091383.1985.9940532

Attinasi, L. C. Jr., (1989). Getting in: Mexican Americans' perceptions of university attendance and the implications for freshman year persistence. Journal of Higher Education, 60(3), 247-277. https://doi.org/10.1080/ 00221546.1989 .11775035

Barnes, J. C., \& Motz, R. T. (2018). Reducing racial inequalities in adulthood arrest by reducing inequalities in school discipline: Evidence from the school-to-prison pipeline. Developmental Psychology, 54(12), 2328. https://doi.org/10.1037/dev0000613

Bell, B. (2016). The impact of the Multicultural Student Services Program on multicultural students first-to-second year persistence at a midwestern private college, Madison, WI: Edgewood College.

Bennett, J., \& Bennett, L. (2003). A review of factors that influence the diffusion of innovation when structuring a faculty training program. Internet and Higher Education, 6(1), 53-63. https://doi.org/10.1016/S1096 $-7516(02) 00161-6$

Biasi, V., Patrizi, N., Mosca, M., \& De Vincenzo, C. (2017). The effectiveness of university counselling for improving academic outcomes and well-being. British Journal of Guidance \& Counselling, 45(3), 248-257. https:// doi.org/10.1080/03069885.2016.1263826

Boggs, C. (1976). Gramsci's Marxism. England: Pluto Press.

Boland, J. M., Adelman, S. I., \& Stevens, J. (1978). Ethnicity as a background factor in college education. Urban Education, 13(1), 65-70. https://doi org/10.1177/0042085978131006

Borg, C., Buttigieg J. A., \& Mayo P., (Eds.). (2002). Gramsci and education. Lanham, MD: Rowman \& Littlefield.

Brogden, H. E., \& Taylor, E. K. (1950). The theory and classification of criterion bias. Educational and Psychological Measurement, 10(2), 159183. https://doi.org/10.1177/001316445001000201

Brownell, S. E., \& Tanner, K. D. (2012). Barriers to faculty pedagogical change: Lack of training, time, incentives, and... tensions with professional identity? CBE-Life Sciences Education, 11(4), 339-346. https://doi. org/10.1187/cbe.12-09-0163

Burt, B. A., Williams, K. L., \& Palmer, G. J. (2019). It takes a village: The role of emic and etic adaptive strengths in the persistence of Black men in engineering graduate programs. American Educational Research Journal, 56(1), 39-74. https://doi.org/10.3102/0002831218789595

Capps, M. P., \& Decosta, F. A. (1957). Contributions of the Graduate Record Examinations and the National Teacher Examinations to the prediction of graduate school success. Journal of Educational Research, 50(5), 383389. https://doi.org/10.1080/00220671.1957.10882393

Carmichael, R. D. (1913). The meaning of graduate study. Science, 37(959), 738-743. https://doi.org/10.1126/science.37.959.738

Carter, T. P., \& Segura, R. D. (1979). Mexican Americans in school: A decade of change. Princeton, NJ: College Board Publications.

Chen, X. (2013). STEM Attrition: College Students' Paths into and out of STEM Fields. Statistical Analysis Report. NCES 2014-001. National Center for Education Statistics.

Collins, K. H. (2018). Confronting color-blind STEM talent development: Toward a contextual model for Black student STEM identity. Journal of Advanced Academics, 29(2), 143-168. https://doi.org/10.1177/1932202×18757958

Creswell, J. W., \& Creswell, J. D. (2017). Research design: Qualitative, quantitative, and mixed methods approaches. Thousand Oaks, CA: Sage Publishing

Creswell, J. W., \& Miller, D. L. (2000). Determining validity in qualitative inquiry. Theory into Practice, 39(3), 124-130. https://doi.org/10.1207/ s15430421tip3903_2

Dawson, D. (1982). Educational hegemony and the phenomenology of community participation. Journal of Educational Thought (JET)/Revue de la Pensée Educative, 150-160. https://doi.org/10.11575/jet.v16i3

Dean, A. M. (1998). Defining and achieving student success. University Faculty and Student Perspectives, IMaster's thesis, Virginia Polytechnic Institute and State University] VTech works.

Delgado, R., \& Stefancic, J. (2000). Critical race theory: The cutting edge. Philadelphia: Temple University Press.
Dezsö, C. L., \& Ross, D. G. (2012). Does female representation in top management improve firm performance? A panel data investigation. Strategic management journal, 33(9), 1072-1089. https://doi.org/10.1002/ smj.1955

Duchek, S., Raetze, S., \& Scheuch, I. (2020). The role of diversity in organizational resilience: a theoretical framework. Business Research, 13(2), 387423. https://doi.org/10.1007/s40685-019-0084-8

Efklides, A., Schwartz, B. L., \& Brown, V. (2018). Motivation and affect in self-regulated learning: Does metacognition play a role? In Schunk, D. H., \& Greene, J. A. (Eds.), Educational psychology handbook series. Handbook of self-regulation of learning and performance (pp. 64-82). England:Routledge: Taylor \& Francis Group.

England, B. J., Brigati, J. R., Schussler, E. E., \& Chen, M. M. (2019). Student anxiety and perception of difficulty impact performance and persistence in introductory biology courses. CBE-Life Sciences Education, 18(2), ar21. https://doi.org/10.1187/cbe.17-12-0284

Foucault, M. (1997). Ethics: Subjectivity and truth (Rabinow, P, Ed.). London: Allen Lane.

Freeman, R. B., \& Huang, W. (2015). Collaborating with people like me: Ethnic coauthorship within the United States. Journal of Labor Economics, 33(S1), S289-S318. https://doi.org/10.1086/678973

Freeman, S., Eddy, S. L., McDonough, M., Smith, M. K., Okoroafor, N., Jordt, H., \& Wenderoth, M. P. (2014). Active learning increases student performance in science, engineering, and mathematics. Proceedings of the National Academy of Sciences USA, 111(23), 8410-8415. https://doi .org/10.1073/pnas.1319030111

Gallup. (2016). Great jobs. Great lives. The Value of career services, inclusive experiences and mentorship for college graduates. Retrieved September 28, 2020, from https://acue.org/wp-content/uploads/2018/11/Gallup -Purdue-Index-Study-Year-3-2016.pdf

Giroux, H. A. (1984). Ideology, culture, and the process of schooling Philadelphia: Temple University Press.

Good, C., Rattan, A., \& Dweck, C. S. (2012). Why do women opt out? Sense of belonging and women's representation in mathematics. Journal of Personality and Social Psychology, 102(4), 700. https://doi.org/10.1037/ a0026659

Goyette, K., \& Xie, Y. (1999). Educational expectations of Asian American youths: Determinants and ethnic differences. Sociology of Education, 22-36. https://doi.org/10.2307/2673184

Gramsci, A. (2000). The Gramsci reader: Selected writings, 1916-1935. New York: NYU Press.

Green, R., \& Macauley, P. (2007). Doctoral students' engagement with information: An American-Australian perspective. Portal: Libraries and the Academy, 7, 317-332 https://doi.org/10.1353/pla.2007.0031

Green, T. L., Sánchez, J., \& Germain, E. (2017). Communities and school ratings: Examining geography of opportunity in an urban school district located in a resource-rich city. Urban Review, 49(5), 777-804. https:// doi.org/10.1007/s11256-017-0421-1

Gregg-Jolly, L., Swartz, J., Iverson, E., Stern, J., Brown, N., \& Lopatto, D. (2016). Situating second-year success: understanding second-year STEM experiences at a liberal arts college. CBE-Life Sciences Education, 15(3), ar43. https://doi.org/10.1187/cbe.16-01-0044

Grimm, J. (2015). Hegemonic framing of Malcolm X and Martin Luther King, Jr., in northeastern newspapers. Howard Journal of Communications, 26(3), 313-332. https://doi.org/10.1080/10646175.2015.1049761

Gullo, G. L., Capatosto, K., \& Staats, C. (2018). Implicit bias in schools: A practitioner's guide. England: Routledge.

Hurtado, S., Alvarado A. R., and Guillermo-Wann C. (2015). Creating inclusive environments: The mediating effect of faculty and staff validation on the relationship of discrimination/bias to students' sense of belonging JCSCORE 1(1), 59-81. https://doi.org/10.15763/issn.2642-2387.2015 .1.1.59-81

Hurtado, S., \& Carter, D. F. (1997). Effects of college transition and perceptions of the campus racial climate on Latino college students' sense of belonging. Sociology of Education, 70(4), 324-345. https://doi.org/ $10.2307 / 2673270$

Kezar, A. (2018). How colleges change: Understanding, leading, and enacting change. Routledge, England: Taylor and Francis Group. 
Killpack, T. L., \& Melón, L. C. (2016). Toward inclusive STEM classrooms: What personal role do faculty play? CBE-Life Sciences Education, 15(3), es3. https://doi.org/10.1187/cbe.16-01-0020

Kunhart, W. E., \& Olsen, L. R. (1959). An analysis of test scores and grades for predicting success of college students in English composition. Journal of Educational Research, 53(2), 79-79. https://doi.org/10.1080/00220671 .1959 .10882616

Ladson-Billings, G., \& Tate, W. F. (2006). Toward a critical race theory of education. Critical race theory in education: All God's children got a song, 11, 30. https://doi.org/10.4324/9781315709796-2

Leman, P. J. (1999). The role of subject area, gender, ethnicity and school background in the degree results of Cambridge University undergraduates. Curriculum Journal, 10(2), 231-252. https://doi.org/10.1080/ 0958517990100205

Lent, R. W., Brown, S. D., \& Hackett, G. (2002). Social cognitive career theory. Career Choice and Development, 4, 255-311.

Lovitts, B. E. (2002). Leaving the ivory tower: The causes and consequences of departure from doctoral study. Lanham, MD: Rowman \& Littlefield.

Lundy, L. (2007). "Voice" is not enough: Conceptualising Article 12 of the United Nations Convention on the Rights of the Child. British Educational Research Journal, 33(6), 927-942. https://doi.org/10.1080/ 01411920701657033

Lygo-Baker, S., Kinchin, I. M., \& Winston, N. E. (Eds.). (2019). Engaging student voices in higher education: Diverse perspectives and expectations in partnership. New York City, NY: Springer. https://doi.org/10.1007/978-3 -030-20824-0

Martinez, L. R., Boucaud, D. W., Casadevall, A., \& August, A. (2018). Factors contributing to the success of $\mathrm{NIH}$-designated underrepresented minorities in academic and nonacademic research positions. CBE-Life Sciences Education, 17(2), ar32. https://doi.org/10.1187/cbe.16-09-0287

May, S., \& Sleeter, C. E. (2010). Critical multiculturalism: Theory and praxis. England: Routledge.

McAlpine, L., \& Amundsen, C. (2009). Identity and agency: Pleasures and collegiality among the challenges of the doctoral journey. Studies in Continuing Education, 31, 109-125. https://doi.org/10.1080/ 01580370902927378

McGee, E. O. (2020). Interrogating structural racism in STEM higher education. Educational Researcher, 49(9), 633-644. https://doi.org/ 10.3102/0013189x20972718

Meyers, L. C., Brown, A. M., Moneta-Koehler, L., \& Chalkley, R. (2018). Survey of checkpoints along the pathway to diverse biomedical research faculty. PLOS ONE, 13(1), e0190606. https://doi.org/10.1371/journal.pone .0190606

Miller, J. W., Martineau, L. P., \& Clark, R. C. (2000). Technology infusion and higher education: Changing teaching and learning. Innovative Higher Education, 24(3), 227-241. https://doi.org/10.1023/b:ihie.0000047412 $64840.1 \mathrm{c}$

Minkler, M., \& Wallerstein, N. (2011). Community-based participatory research for health: From process to outcomes. Hoboken, NJ: Wiley.

Muñoz, S. M., \& Maldonado, M. M. (2012). Counterstories of college persistence by undocumented Mexicana students: Navigating race, class, gender, and legal status. International Journal of Qualitative Studies in Education, 25(3), 293-315. https://doi.org/10.1080/09518398.2010.529850

National Science Foundation. (2018). Science and engineering indicators. Washington, DC.

Nouwen, W., \& Clycq N. (2018). The role of teacher-pupil relations in stereotype threat effects in Flemish secondary education. Urban Education 54(10), 1551-1580. https://doi.org/10.1177/0042085916646627

Oh, C. J., \& Kim, N. Y. (2016). "success is relative": Comparative social class and ethnic effects in an academic paradox. Sociological Perspectives, 59(2), 270-295. https://doi.org/10.1177/0731121415587115

O'Shea, S., \& Delahunty, J. (2018). Getting through the day and still having a smile on my face! How do students define success in the university learning environment? Higher Education Research \& Development, 37(5), 1062-1075. https://doi.org/10.1080/07294360.2018.1463973

Park, J. J., Kim, Y. K., Salazar, C., \& Eagan, M. K. (2020). Racial discrimination and student-faculty interaction in STEM: Probing the mechanisms influencing inequality. Journal of Diversity in Higher Education. https://doi .org/10.1037/dhe0000224
Panos, R. J., \& Astin, A. W. (1968). Attrition among college students. American Educational Research Journal, 5(1), 57-72. https://doi.org/10.3102/ 00028312005001057

Pratt, N. (2004). Bringing politics back in: Examining the link between globalization and democratization. Review of International Political Economy, 11(2), 311-336. https://doi.org/10.1080/0969229042000249831

Project Implicit. (2011). Home page. Retrieved October 1, 2020, from https:// implicit.harvard.edu/implicit/index.jsp

Racial Equity Tools. (2020). Communicating implicit bias. Retrieved October 1 2020, from www.racialequitytools.org/act/communicating/implicit-bias

Reynolds, A., \& Lewis, D. (2017). Teams solve problems faster when they're more cognitively diverse. Harvard Business Review, Retrieved October 25, 2020, from https://hbr.org/2017/03/teams-solveproblems-faster -when-theyre-morecognitively-diverse

Richardson, K., Clark, Z., Gaines, M., Kingi, H., Miller, S., Pearson, W., Jr., \& Richardson, L. (2018). Āwhina revolution: A Bayesian analysis of undergraduate and postgraduate completion rates from a program for Māori and Pacific success in STEM disciplines. CBE-Life Sciences Education, 17(1), ar15. https://doi.org/10.1187/cbe.17-07-0117

Robertson, M., \& Hall, E. (1964). Predicting success in graduate study. Journal of General Psychology, 71, 359

Rose, S. (1976). Scientific racism and ideology: The IQ racket from Galton to Jensen. In Rose, H., \& Rose, S. (Eds.), The political economy of science: Ideology of/in the natural sciences (pp. 112-141). London: Macmillan Education UK. https://doi.org/10.1007/978-1-349-15725-9_7

Rosenbaum, J. E. (1976). Making inequality; the hidden curriculum of high school tracking, New York City, NY: Wiley.

Rowland, A. A., Knekta, E., Eddy, S., \& Corwin, L. A. (2019). Defining and measuring students' interest in biology: An analysis of the biology education literature. CBE-Life Sciences Education, 18(3), ar34. https://doi .org/10.1187/cbe.19-02-0037

Schnoes, A. M., Caliendo, A., Morand, J., Dillinger, T., Naffziger-Hirsch, M., Moses, B., ... \& O'Brien, T. C. (2018). Internship experiences contribute to confident career decision making for doctoral students in the life sciences. CBE-Life Sciences Education, 17(1), ar16. https://doi.org/10.1187/ cbe.17-08-0164

Seidel, S. B., Reggi, A. L., Schinske, J. N., Burrus, L. W., \& Tanner, K. D. (2015). Beyond the biology: A systematic investigation of noncontent instructor talk in an introductory biology course. CBE-Life Sciences Education, 14(4), ar43. https://doi.org/10.1187/cbe.15-03-0049

Solorzano, D. G. (1997). Images and words that wound: Critical race theory, racial stereotyping, and teacher education. Teacher Education Quarterly, 24(3), 5-19.

Solorzano, D. G., \& Yosso, T. J. (2001). From racial stereotyping and deficit discourse toward a critical race theory in teacher education. Multicultural Education, 9(1), 2.

Southworth, S., \& Mickelson, R. A. (2007). The interactive effects of race, gender and school composition on college track placement. Social Forces, 86(2), 497-523. https://doi.org/10.1093/sf/86.2.497

Sowell, R., Allum, J., \& Okahana, H. (2015). Doctoral initiative on minority attrition and completion. Washington, DC: Council of Graduate Schools.

Spady, W. G. (1970). Dropouts from higher education: An interdisciplinary review and synthesis. Interchange, 1(1), 64-85. https://doi.org/10.1007/ BF02214313

Sutantoputri, N. W., Sutantoputra, A., Tirtowalujo, I., Murniati, J., \& Purwanti, M. (2020). Significance of sociocultural factors in attribution of educational outcomes and motivation goals. In Suryani, A., Tirtowalujo, I., \& Masalam, I, H. (Eds.), Preparing Indonesian youth (pp. 185-202). Netherlands: Brill Sense.

Sweitzer, V. B. (2009). Towards a theory of doctoral student professional identity development: A developmental networks approach. Journal of Higher Education, 80,1-33. https://doi.org/10.1080/00221546.2009.11772128

Tachine, A. R., Cabrera, N. L., \& Yellow Bird, E. (2017). Home away from home: Native American students' sense of belonging during their first year in college. Journal of Higher Education, 88(5), 785-807. https://doi .org/10.1080/00221546.2016.1257322

Tate IV, W. F. (2008). "Geography of opportunity": Poverty, place, and educational outcomes. Educational Researcher, 37(7), 397-411. https://doi org/10.3102/0013189×08326409 
Tibbetts, Y., Harackiewicz, J. M., Priniski, S. J., \& Canning, E. A. (2016) Broadening participation in the life sciences with social-psychological interventions. CBE-Life Sciences Education, 15(3), es4. https://doi org/10.1187/cbe.16-01-0001

Tierney, W. G. (1992). Official encouragement, institutional discouragement: Minorities in academe-The Native American experience (Interpretive Perspectives on Education and Policy). New York City, NY: Ablex Publishing.

Thompson, J. J., \& Jensen-Ryan, D. (2018). Becoming a "science person": Faculty recognition and the development of cultural capital in the context of undergraduate biology research. CBE-Life Sciences Education, 17(4), ar62. https://doi.org/10.1187/cbe.17-11-0229

Tinto, V. (1975). Dropout from higher education: A theoretical synthesis of recent research. Review of Educational Research, 45(1), 89-125. https:// doi.org/10.3102/00346543045001089

Tinto, V. (1993). Leaving college: Rethinking the causes and cures of student attrition (2nd ed.). Chicago: University of Chicago Press. https://doi .org/10.7208/chicago/9780226922461.001.0001

United Nations. (2002) Concluding observations of the Committee on the Rights of the Child: United Kingdom of Great Britain and Northern Ireland (UN/CRC/C/15/Add.188). Geneva.

United Nations. (2003) Committee on the Rights of the Child general comment no. 5 (2003): Implementation (UN/ CRC/GC/2003/1) Geneva.

United Nations. (2009). Committee on the Rights of the Child general comment no. 12 (2009): The right of the child to be heard (UN/CRC/C/12). Geneva.
Vaught, S. E. (2011). Racism, public schooling, and the entrenchment of white supremacy: A critical race ethnography. Albany, NY: SUNY Press.

Vescovelli, F., Melani, P., Ruini, C., Ricci Bitti, P. E., \& Monti, F. (2017). University counseling service for improving students' mental health. Psychological Services, 14(4), 470. https://doi.org/10.1037/ser0000166

Vespa, J., Armstrong, D. M., \& Medina, L. (2018). Demographic turning points for the United States: Population projections for 2020 to 2060. Washington, DC: U.S. Department of Commerce, Economics and Statistics Administration, U.S. Census Bureau.

Walck-Shannon, E. M., Cahill, M. J., McDaniel, M. A., \& Frey, R. F. (2019). Participation in voluntary re-quizzing is predictive of increased performance on cumulative assessments in introductory biology. CBE-Life Sciences Education, 18(2), ar15. https://doi.org/10.1187/cbe.18-08-0163

Wilson, M. A., DePass, A. L., \& Bean, A. J. (2018). Institutional interventions that remove barriers to recruit and retain diverse biomedical $\mathrm{PhD}$ students. CBE-Life Sciences Education, 17(2), ar27. https://doi.org/10.1187/ cbe.17-09-0210

Yancy, G. (2016). Black bodies, white gazes: The continuing significance of race in America. Lanham, MD: Rowman \& Littlefield.

Yao, C. W. (2015). Sense of belonging in international students: Making the case against integration to US institutions of higher education. Faculty Publications in Educational Administration, 7(45). https://digitalcommons unl.edu/cehsedadfacpub/45

Yosso, T. J. (2005). Whose culture has capital? A critical race theory discussion of community cultural wealth. Race Ethnicity and Education, 8(1), 69-91. https://doi.org/10.1080/1361332052000341006 